\title{
Oil SANDS Mining REClamation in AlbERTA: A DISCUSSION OF THE PRIOR REGIME AND THE NeW Mine Financial SECURITy Program
}

\author{
CHRYSTEN PERRY $^{*}$ AND CRAIG SALOFF ${ }^{* *}$
}

This article discusses the oil sands mining regime in Alberta, focusing on the prior reclamation regime, its shortcomings, and the events that led to its overhaul. The newly enacted Mine Financial Security Program (Alberta) is discussed, together with an analysis of whether the problems under the prior reclamation regime have been adequately addressed. Finally, the authors discuss matters that should be taken into account when drafting agreements that involve the funding or performance of reclamation obligations in oil sands mining projects in Alberta.
Cet article porte sur le régime minier des sables bitumineux en Alberta et accorde une attention spéciale à l'ancien régime de régénération, ses faiblesses, et les événements qui ont abouti à la révision. Le nouveau Mine Financial Security Program (Alberta) est discuté au même titre que la question de savoir si les problèmes occasionnés par l'ancien régime de régénération ont été abordés adéquatement. Enfin, les auteurs discutent de sujets qui devraient entrer en compte lors de la rédaction d'entente impliquant le financement ou la performance des obligations de régénération dans les projets miniers des sables bitumineux de l'Alberta.

\section{TABLE OF CONTENTS}

I. INTRODUCTION . . . . . . . . . . . . . . . . . . . . . . . . . . . . . . . 278

II. General NatURE Of CANAdian Oil SANDS . . . . . . . . . . . . . . 279

A. GENERAL INFORMATION . . . . . . . . . . . . . . . . . . . . . . 279

B. WHAT ARE THE OIL SANDS? . . . . . . . . . . . . . . 279

C. Oil Genesis, Migration, And Biodegradation . . . . . . . . . 280

D. Commercial Production ANd REClAmation . . . . . . . . . . . . . 280

E. A BRIEF DESCRIPTION OF OIL SANDS MINING . . . . . . . . . . . . . . 282

III. THE NEED fOR AN OIL SANDS Mine RECLAMATION REgIME . . . . . . . 282

IV. The PRior Reclamation REgime $\ldots \ldots \ldots \ldots \ldots \ldots \ldots \ldots \ldots \ldots . \ldots \ldots$

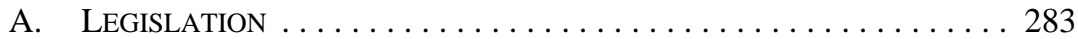

B. EARLy AtTEMPTS TO IMPROVE THE SySTEM . . . . . . . . . . . . . 287

C. AdDITIONAL ISSUES WITH THE PRIOR

RECLAMATION REGIME . . . . . . . . . . . . . . . . . . . . . . . . . . . . 290

V. The New Mine Financial Security Program $\ldots \ldots \ldots \ldots \ldots \ldots . . \ldots 293$

A. The Base Security Deposit . . . . . . . . . . . . . . . . . . . . . . 294

B. The AsSet SAFETy FActor Deposit . . . . . . . . . . . . . . . . . . . 294

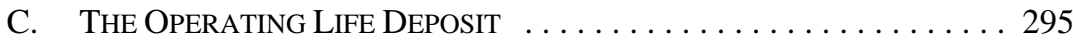

D. The Outstanding Reclamation DePOSiT . . . . . . . . . . . 296

E. Providing the NeCESSARy SECURITY . . . . . . . . . . . . . . . . 297

F. CERTIFICATION OF MFSP ASSET AND Liability DATA . . . . . . . . . 297

VI. RECLAMATION AND SECURITY ISSUES TO CONSIDER

When Drafting Joint Venture AgREEMENTS . . . . . . . . . . 300

* $\quad$ Partner, Macleod Dixon LLP, Calgary, Alberta.

** General Counsel, Total E \& P Canada Ltd. The views expressed herein are those of the authors and not of Macleod Dixon LLP or Total E\&P Canada Ltd. The insightful assistance of Ray Hansen, QC, General Counsel, Syncrude Canada Ltd, and Fraser Bush, Macleod Dixon LLP, in the preparation of this article are gratefully acknowledged. 
A. Parties Eligible to Provide Security . . . . . . . . . . . . 301

B. Realization of Security Upon Operator Default . . . . . . . 302

C. Full FinANCIAL SECURITY NOT REQUIRED UNTIL LATER

IN AN OIL SANDS PROJECT's LIFE . . . . . . . . . . . . . . . . . 302

D. REFUND OF SECURITY DEPOSITS TO NON-OPERATORS $\ldots \ldots \ldots 303$

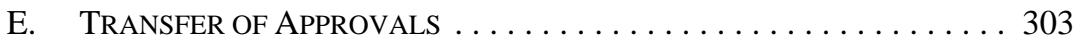

F. RETURN OF SECURITY UPON ISSUANCE

OF A RECLAMATION CERTIFICATE . . . . . . . . . . . . . . . 304

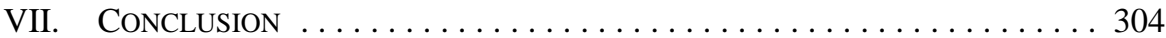

\section{INTRODUCTION}

Oil sands can be found all around the world, but Alberta claims the largest known deposits. The development of Alberta's oil sands resources generates many significant benefits to the Province of Alberta and the rest of Canada. Alberta's oil sands may be Canada's greatest buried energy treasure. In fact, the Canadian government has predicted that their development will assist in making Canada one of the world's energy superpowers. ${ }^{1}$ Clearly the oil sands are a very significant provincial resource. However, the international spotlight that has focused on the oil sands in recent years has also highlighted concerns that environmental issues are being ignored by the Government of Alberta, in favour of development.

This article was initially conceived to review and evaluate the legislative regime that was in force in Alberta prior to 1 April 2011 (the "prior reclamation regime”) in relation to oil sands mining reclamation, to identify the shortcomings of that regime vis-à-vis the industry operators and other stakeholders, and to discuss issues that should have been of concern to working interest participants in oil sands mines from a joint development and reclamation standpoint. However, as this article was being prepared, the Government of Alberta announced its new Mine Financial Security Program (MFSP), which is intended to address the inadequacies of the prior reclamation regime and refine the legislative requirements applicable to oil sands mine reclamation. ${ }^{2}$ As they say in show business, timing is everything.

As a result of the announcement of the MFSP, this article will review the prior reclamation regime and discuss its shortcomings, and then evaluate whether the new MFSP regime satisfactorily addresses them. Finally, this article includes a section on "drafting” matters that practitioners may want to consider when putting into place agreements to jointly develop, produce, and reclaim oil sands mines in Alberta.

But first, a bit of background...

1 Prime Minister Stephen Harper, “Address by the Prime Minister at the Canada-UK Chamber of Commerce” (Address delivered at the Canada-UK Chamber of Commerce, 14 July 2006), online: Prime Minister of Canada Stephen Harper <http://pm.gc.ca/eng/media.asp?id=1247>.

2 The MFSP came into effect in March 2011 upon adoption of the Conservation and Reclamation Amendment Regulation, Alta Reg 34/2011, s 2. 


\section{General Nature of Canadian OIL SANDS}

\section{A. GENERAL INFORMATION}

The Alberta oil sands are located in three main areas. The largest deposit, known as the Athabasca Oil Sands, straddles the Athabasca River in northeastern Alberta. The Peace River Oil Sands and the Cold Lake Oil Sands deposits lie west and south of the Athabasca Oil Sands respectively, and, while each is smaller than the Athabasca Oil Sands by almost half, still contain significant reserves. Combined, the three deposits cover more than 140,000 square kilometres - an area about as big as Florida ${ }^{3}$ and are estimated to contain in-place bitumen resources of 1.8 trillion barrels. ${ }^{4}$ Of this, 171.3 billion barrels are proven, which represents about 13 percent of the world's total oil reserves. ${ }^{5}$

It is estimated that only about 10 percent of these volumes can currently be recovered using known technology. ${ }^{6}$ Accordingly, there is considerable potential for the estimate of recoverable reserves to increase as advances are made in recovery technology. Of the 140,000 square kilometres of bitumen deposits, about 34 billion barrels (or 4800 square kilometres, on an areal basis) lie within 75 metres of the surface of the land and can be produced through open pit mining. ${ }^{7}$ The remaining oil sands (about 136 billion barrels) are located in such deep formations that they currently can only be extracted through in situ ("in place”) drainage techniques, the most widely used of which is steam assisted gravity drainage (SAGD). ${ }^{8}$ In situ production typically involves methods similar to conventional crude oil development and enhanced recovery, where steam and/or solvents are injected into the reservoir to reduce the viscosity of the bitumen. The quality of an oil sands deposit depends largely on the degree of saturation of bitumen within the deposit and the thickness of the saturated interval. Almost all of the oil sands rights are owned by the Alberta government, with only about 3 percent held by the Government of Canada or as freehold title. ${ }^{9}$

\section{B. WHAT ARE THE OIL SANDS?}

The Oil Sands Discovery Centre, in their Facts about Alberta's Oil Sands and its Industry, describe the oil sands as follows:

Oil sands are hydrophilic or waterwet. ${ }^{10}$ Each grain of sand is covered by a film of water, which is then surrounded by a slick of heavy oil (bitumen). The sands are bonded firmly together by grain-to-grain contact.

Alberta Geological Survey, “Alberta Oil Sands” (7 April 2011), online: Alberta Geological Survey $<$ http://www.ags.gov.ab.ca/energy/oilsands/alberta_oil_sands.html>. See also Pembina Institute, “Alberta's Oil Sands” (March 2011), online: Pembina Institute <http://www.pembina.org/oil-sands/ 0s01/alberta>.

4 Alberta Environment, Alberta's Oil Sands: Opportunity, Balance (Edmonton: Government of Alberta, 2008) at 2.

Alberta Energy, "Facts and Statistics,” online: Alberta Energy <http://www.energy.gov.ab.ca/Oil Sands/791.asp>.

Ibid.

Ibid.

Ibid.

Ibid.

The Canadian Oxford Dictionary defines hydrophilic as "readily mixable with or wettable by water." Katherine Barber, ed, Canadian Oxford Dictionary (Don Mills, ON: Oxford University Press, 1998) sub verbo "hydrophilic." 
The sand is composed of $92 \%$ quartz with traces of mica, rutile, zircon, tourmaline, titanium, nickel, iron, vanadium and pyrite. The sand is triangular in shape making it very abrasive. On the Moh's hardness scale, with diamond being 10 , [and talc being 1, ] oil sand is $7.4{ }^{11}$

In the winter, the water layer in the oil sands will freeze, making the substance as hard as concrete, and in the warmer summer months, as soft as molasses, "prompting one observer to compare extracting oil from the sand to removing honey from a bowl of sugar." " Oil sands oil is distinct in other ways as well. For example, oil sands oil is heavy with a higher specific gravity than water. This means that oil sands oil sinks rather than floats in water, unlike conventionally produced oils. ${ }^{13}$ Evidently, this oil cannot be produced by traditional methods of drilling for and pumping it. There is no gas pressure to drive the oil to wells, and in any event, the oil is too heavy and viscous due to the temperatures in the formations in which it is found to be taken out by that gas pressure method.

\section{OIL Genesis, Migration, AND Biodegradation}

The actual age of the source rocks for the Alberta oil sands deposits is still not known. What is known is that the light oil originated from the deeper portions of the Western Canada Sedimentary Basin in pre-Cretaceous formations and then migrated long distances to the current location. ${ }^{14}$ Oil was collected in the sands of Fort McMurray, which in turn acted as the "main conduit for migration. It is speculated that the migration path was at least 360 kilometres for the Athabasca Deposit and at least 80 kilometres for the Peace River Deposits. The lighter oils were then subjected to biodegradation, transforming them into bitumen."15 This biodegradation resulted from microbes, found in oxygenated water, decomposing the trapped oil. This action "decomposed the lighter hydrocarbon molecules, leaving more heavy complex molecules, heavy minerals and sulphur behind.... It has been estimated that prior to biodegradation, the original volume of oil in the oil sands was two to three times as large as it is today."16

\section{Commercial Production AND Reclamation}

Commercial production of Alberta's oil sands began with Great Canadian Oil Sands' (now Suncor's) first mine in $1967 .{ }^{17}$ This was followed in 1978 by Syncrude’s Base Mine, which

Oil Sands Discovery Centre, Facts about Alberta's Oil Sands and its Industry (Fort McMurray: Government of Alberta, 2009) at 8, online: Oils Sands Discovery Centre <http://history.alberta.ca/ oilsands/docs/facts_sheets09.pdf $>$ [footnote added].

12 Paul Chastko, Developing Alberta’s Oil Sands: From Karl Clark to Kyoto (Calgary: University of Calgary Press, 2004) at 6, citing Clayton Jones, “Alberta, Canada’s Energy Giant, Turns Sand Into Black Gold,” The Christian Science Monitor (20 November 1980), online: The Christian Science Monitor <http://www.csmonitor.com/1980/1120/112039.html>.

Chastko, ibid at 6.

National Energy Board (NEB), Canada's Oil Sands: A Supply and Market Outlook to 2015 (Calgary: National Energy Board, 2000) at 6, online: National Energy Board <http://ww.neb-one.gc.ca/clfnsi/rnrgynfmtn/nrgyrprt/lsnd/lsndsspplymrkt20152000-eng.pdf>.

Ibid.

Ibid [emphasis added].

Government of Alberta, “Alberta’s oil sands: Facts About Energy Research and Technology,” online: Government of Alberta <http://www.oilsands.alberta.ca/FactSheets/FS-EnergyResearchAndTechnology. $\operatorname{pdf}>$. 
is the biggest mine of any kind in the world.$^{18}$ The Albian Oil Sands consortium commenced operation of its Muskeg River Mine in 2002 and Canadian Natural Resources started its Horizon Mine in 2009. ${ }^{19}$

Of the 4,800 square kilometres of mineable deposits, approximately 663 square kilometres (66,342 hectares) are currently disturbed by oil sands mining, which is 0.16 percent of Alberta's boreal forest. ${ }^{20}$ Today, from a reclamation standpoint, 46.5 square kilometres (4,654 hectares) are classified as "permanent reclaimation," while only about 1 square kilometre (104 hectares) is “certified reclaimed."”1

The Energy Resources Conservation Bord (ERCB) reports that, all told, seven oil sands mining projects and 26 commercial in situ projects have been approved, together with almost 130 primary recovery and 12 experimental schemes. ${ }^{22}$ In 2009, oil sands producers extracted approximately 1.5 million barrels of bitumen per day, ${ }^{23}$ representing more than 75 percent of Alberta's total crude oil production. This rate is expected to increase to about 2.7 million barrels per day in $2015^{24}$ with an annual total production of one billion barrels by $2019,{ }^{25}$ or 3.2 million barrels of crude bitumen per day. Today, mining extraction accounts for approximately 60 percent of the bitumen that is produced each day in Alberta. ${ }^{26}$ Conventional oil and gas production in western Canada has been on the decline since the early 1990s, for a number of reasons. ${ }^{27}$ However, the world's appetite for oil has steadily increased, putting pressure on the development of Alberta's oil sands.

The extent of these projects makes it obvious that the oil sands are more than just significant to the oil industry. They have led to Canada's reputation as a worldwide energy superpower; however, this image has recently taken a significant beating on many fronts, largely as a result of the drastic impact that oil sands mining projects have had on the landscape, water sources, and wildlife habitat in northern Alberta, and the resulting concerns that the Province of Alberta's reclamation strategies and methodologies were not adequate to ensure acceptable reclamation for all stakeholders.

Government of Alberta (Energy), "Mining in Alberta,” online: Government of Alberta <http://www. energy.alberta.ca/minerals/1084.asp>.

Terra Simieritsch, Joe Obad \& Simon Dyer, Tailings Plan Review: An Assessment of Oil Sands Company Submissions for Compliance with ERCB Directive 074: Tailings Performance Criteria and Requirements for Oil Sands Mining Schemes (Drayton Valley: Pembina Foundation and Water Matters, 2009) at 11, 15, online: Pembina Institute <http://www.pembina.org/pub/1934>.

Government of Alberta, “Oil Sands Reclamation,” online: Government of Alberta <http://www. oilsands.alberta.ca/FactSheets/fs_Reclamation_online.pdf> [Reclamation].

Ibid.

ERCB, "Enerfaqs: Frequently Asked Questions on the Development of Alberta's Energy Resources" at 3, online: ERCB < http://www.ercb.ca/portal/server.pt/gateway/PTARGS_0_0_320_0_0_43/http\%3B/ ercbContent/publishedcontent/publish/ercb_home/public_zone/ercb_process/ener faqs/enerfaqs12.aspx $>$.

Government of Alberta, “Alberta’s oil sands: Facts About the Resource,” online: Government of Alberta <http://www.oilsands.alberta.ca/FactSheets/FS-Resource.pdf >.

Supra note 14 at 13.

Supra note 23 at 2.

ERCB, “Supply and Disposition of Crude Oil Equivalent,” online: ERCB <http://www.ercb.ca/docs/ products/sts/st3/oil_current.xls>.

One reason is the higher development costs compared to unconventional development. 


\section{E. A BRIEF DESCRIPTION OF OIL SANDS Mining}

Oil sands mining projects entail massive land disturbances. Prior to digging the bitumen, rivers need to be diverted, trees removed, and wetlands drained and excavated. The topsoil, muskeg, and overburden is removed and stored using large shovels and trucks, some as large as three-story houses. In some cases, the overburden is used to construct large dykes used for tailings. Processing facilities and other necessary infrastructure need to be built. Bitumen is then removed from the mined substances at an extraction plant using a process involving hot water. During oil sands processing, sulphur and coke by-products are produced and stored on-site. ${ }^{28}$

Reconstructing functional landscapes following mining is a complicated process. As the overburden is removed, the removed earth is mixed and therefore cannot be replaced in intact stratigraphic layers during the reclamation process. There is an inevitable increase in volume with backfilling, making re-contouring and levelling of the final landscape a challenge. As subsoil permeability increases after the bitumen has been extracted from the sand, this in turn affects groundwater flow, direction, and quality. In addition, water tables will either rise or fall. Reclamation covers need to be carefully constructed, as they are intended to have the same soil profiles as the pre-disturbance landscape and must support the establishment of boreal forest ecosystems, including uplands and wetlands, while minimizing detrimental effects of salts released from overlying overburden material into the root zone. The sand, oil, and water in the tailings ponds must settle into distinct layers so the liquid can be drained, allowing reclamation to proceed on a solid surface. ${ }^{29}$

To understand the enormity of the undertaking, consider that reclamation of a mine site is implemented over an area that is potentially hundreds of hectares in size and may occur over a period of decades. Ultimately, judging the overall success of the reclamation of oil sands mine sites will depend on their "ability to promote the restoration of natural cycles" and the eventual establishment of a sustainable boreal forest. ${ }^{30}$

\section{The NeED FOR AN OIL SANDS Mine Reclamation REgIME}

The regulatory regime governing the oil sands is based on principles of conservation; namely, to optimize or maximize the recovery of oil and gas while minimizing the environmental impact of the operators. Despite this laudable goal, there were many who were highly critical of the prior reclamation regime and, in some cases, they had good reason. The legislation that previously dictated the process and standards for reclamation was not initially designed for oil sands mining. Rather than introducing new legislation tailored to oil sands mining projects, amendments to existing legislation, along with policy changes, were implemented from time to time with the result that the legislators were constantly playing

$28 \quad$ Pierre Gosselin et al, The Royal Society of Canada Expert Panel: Environmental and Health Impacts of Canada's Oil Sands Industry (Ottawa: The Royal Society of Canada, 2010) at 169, online: The Royal Society of Canada <http://www.rsc.ca/documents/expert/RSC\%20report\%20complete\%20secured\%20 9Mb.pdf $>$ [Expert Panel Report].

Ibid.

Sean K Carey, "Growing Season Energy and Water Exchange From an Oil Sands Overburden Reclamation Soil Cover, Fort McMurray, Alberta, Canada” (2008) 22:15 Hydrological Processes 2847 at 2847. 
catch-up. ${ }^{31}$ This was largely a result of the pace and intensity of oil sands development, which "vastly exceeded" the initial expectations of the Government of Alberta. ${ }^{32}$ For example, in 1995, the National Task Force on Oil Sands Strategies, comprised of 30 companies and government agencies, released a 25-year strategy calling for an investment of $\$ 21$ billion to $\$ 25$ billion and a tripling of production. ${ }^{33}$ In fact, production tripled and \$30 billion was invested within eight years. ${ }^{34}$ As a result, there is a widely held view that ecological lines were crossed even before the issues were publicly acknowledged or identified, and further, that early opportunities to establish environmental policies and standards were missed. ${ }^{35}$

Today, the industry is under ever-increasing scrutiny over the environmental disturbances created by oil sands mining. This is partly because the prior reclamation regime did not adequately address the unique problems associated with oil sands mining reclamation. Having a well-respected reclamation program for oil sands mining will only improve Alberta's reputation vis-à-vis foreign investors and would likely increase these investors' interest in oil sands oil as a foreign import. Further, Alberta must be viewed as seriously dealing with environmental problems in order to meet the requirements of foreign investment policies. As a result, industry and government have been working to put fiscally and operationally viable programs in place for the full and progressive reclamation of oil sands development - where producers are incentivized to reclaim the environment at standards that are acceptable to, and well understood by, all stakeholders. As part of these efforts, the new MFSP regime has been recently enacted as law in Alberta. See the discussion of the prior reclamation regime, and some of the reasons why the new MFSP will be a vast improvement, below.

\section{The Prior Reclamation Regime}

\section{A. Legislation}

Alberta's oil sands mine reclamation regime was, and still is, prescribed by the Environmental Protection and Enhancement Act, ${ }^{36}$ the Conservation and Reclamation Regulation, ${ }^{37}$ and the Activities Designation Regulation. ${ }^{38}$ Pursuant to section 137 of the

Steven A Kennett, "Closing the Performance Gap: The Challenge for Cumulative Effects Management in Alberta's Athabasca Oil Sands Region” (Calgary: Canadian Institute of Resources Law, 2007) at 55. Ibid at 1. Evidence of "catch-up” may be found in Directive 074: Tailings Performance Criteria and Requirements for Oil Sands Mining Schemes, released by the ERCB in February 2009. This directive applied to all oil sands mining operations and required the reduction of fluid tailings and their capture and conversion to deposits that could bear the weight of heavy equipment. ERCB, Directive 074: Tailings Performance Criteria and Requirements for Oil Sands Mining Schemes (Calgary: ERCB, 2009) [Directive 074]. While anxious to put in place a program to address the adverse impacts of tailings from oil sands mining on the environment, this directive was issued in advance of the Government of Alberta establishing its official policy on tailings. We understand that the government's tailings management policy is soon to be announced and is expected to be more detailed and comprehensive than Directive 074.

33 National Task Force on Oil Sands Strategies of the Alberta Chamber of Resources, The Oil Sands: A New Energy Vision for Canada (Edmonton: Alberta Chamber of Resources, 1995) at 4-6.

34 Curtis Gillespie, "Scar Sands," Canadian Geographic (June 2008), online: Canadian Geographic <http://www.canadiangeographic.ca/magazine/jun08/feature_tar_sands.asp>.

Kennett, supra note 31 at 55.

RSA 2000, c E-12 [EPEA].

Alta Reg 115/1993 [CRR].

Alta Reg 276/2003 [ADR]. 
EPEA, an operator has a duty to conserve and reclaim all specified land and obtain a reclamation certificate from Alberta Environment. “Operator” is defined in section 134(b) of the EPEA as:

(i) an approval or registration holder who carries on or has carried on an activity on or in respect of specified land pursuant to an approval or registration [under the EPEA],

(ii) any person who carries on or has carried on an activity on or in respect of specified land other than pursuant to an approval or registration,

(iii) the holder of a licence, approval or permit issued by the Energy Resources Conservation Board or the Alberta Utilities Commission for purposes related to the carrying on of an activity on or in respect of specified land,

(iv) a working interest participant in ... a mine ${ }^{39} \ldots$ on, in or under specified land,

(v) the holder of a surface lease for purposes related to the carrying on of an activity on or in respect of specified land,

(vi) a successor, assignee, executor, administrator, receiver, receiver-manager or trustee of a person referred to in any of subclauses (i) to (v), and

(vii) a person who acts as principal or agent of a person referred to in any of subclauses (i) to (vi).

An "activity" is defined, inter alia, as the construction, operation, or reclamation of an oil sands site. ${ }^{40}$ Pursuant to sections 60 and 61 of the EPEA, and section 5(1) and Schedule 1, Division 3 of the $A D R$, an approval is required for the construction, operation, or reclamation of an oil sands mine. Further, section 10 of the Oil Sands Conservation Act ${ }^{41}$ requires a person to seek an ERCB approval where they wish to "construct facilities for a scheme or operation or commence or continue a scheme or operation for the recovery of oil sands." Thus, the definition of "operator" is quite broad and covers Alberta Environment oil sands mine approval holders, ERCB oil sands approval holders, and working interest participants in oil sands mines, among others. In addition, the broad definition of "operator" means that more than one person may be required to provide security and reclaim the specified land in respect of an oil sands project.

"Specified land" is defined by section 134(f) of the EPEA as "specified land within the meaning of the regulations on or in respect of which an activity is or has been carried on." Section 1(t) of the CRR defines "specified land," inter alia, as "land that is being or has been used or held for or in connection with, the construction, operation or reclamation of a mine."42

"Mine" is defined in section $1(\mathrm{kk})$ of the EPEA as "any opening in, excavation in or working of the surface or subsurface for the purpose of working, recovering, opening up or proving ... oil sands or an oil sands bearing substance, and includes any associated infrastructure.” EPEA, supra note 36, s 1(kk). Ibid, s 1(a) and Schedule of Activities, s 5(c).

RSA 2000, c O-7.

As the term "mine" is not defined in the CRR, the definition provided in EPEA is applicable. See also Interpretation Act, RSA 2000, c I-8, s 13(b). 
Section 84 of the EPEA requires an applicant for or holder of an EPEA approval to "provide financial or other security and carry insurance in respect of the activity" to which the approval relates, where required by the regulations. ${ }^{43}$ Under the prior reclamation regime, section 17(1)(a) of the CRR stated that an operator must post security before an approval was issued in respect of an activity listed in Schedule 1, Division 3 of the $A D R$. As noted above, one of the activities listed in Schedule 1, Division 3 of the $A D R$ is the construction, operation, or reclamation of an oil sands mine. ${ }^{44}$ Thus, when applying for an approval for an oil sands mining operation under the prior reclamation regime, the operator was required to post security before the approval was issued. ${ }^{45}$

Also under the prior reclamation regime, section 18(1) of the $C R R$ stated that "security for an approval shall be in an amount determined by the Director to be sufficient to ensure completion of conservation and reclamation on the specified land as required by the [EPEA] and its regulations." This is based on:

(a) the estimated costs of conservation and reclamation submitted by the operator,

(b) the nature, complexity and extent of the activity,

(c) the probable difficulty of conservation and reclamation, giving consideration to such factors as topography, soils, geology, hydrology and revegetation, and

any other factors the Director considers to be relevant. ${ }^{46}$

As well, the operator was required to provide evidence in support of the cost estimate required by section $18(1)$ (a) in accordance with information documents. ${ }^{47}$

As can be seen by the emphasized words, above, the previous legislation granted the Director wide discretion to determine the required security for reclamation purposes. This occurred despite no formal public policy, regulations, or guidelines that standardized how security was to be calculated or estimated by operators, or assessed by Alberta Environment. As the authors note later in this article, this discretion may have been the reason why, on the

43 This requirement “does not apply to the Government or a Government agency.” EPEA, supra note 36, s 84(2).

$44 \quad$ Section 17.1 of the $C R R$ provides an exception from the security requirements for:

a) an operator that is a local authority;

b) an operator that applies for an approval for the construction of a pipeline;

c) an operator that has, or applies for, an approval for the construction, operation or reclamation of an oil production site; or

d) an operator that has, or applies for, an approval for the construction, operation or reclamation of a transmission line.

45 Similarly, section 135 of EPEA requires an operator to provide financial or other security "in respect of the activity carried on by the operator on specified land" where required by the regulations, although this requirement "does not apply to the Government or a Government agency." Although there is some overlap, section 135 seems to speak to the ongoing requirement of an operator to provide and maintain security, whereas section 84 is broader and covers both applicants for and holders of an approval. As section 17(1) of the $C R R$ requires operators to provide security before an approval is issued, i.e. at the application stage, it is likely that section 84 is the more applicable of the two sections.

46 Supra note 37, s 18(1) [emphasis added]. "Director" means the person designated as Director for the purposes of EPEA by the Minister. EPEA, supra note 36, s 1(r).

47 CRR, ibid, s 18(2). "Information documents" are defined by section 1(h) of the CRR as "any document issued by the Director that provides direction and guidance on matters respecting conservation and reclamation." 
bankruptcy of the Smoky River Coal Mine, the security held by the government for that mine's reclamation was reportedly significantly short of the required amount ${ }^{48}-$ an event that was the catalyst for the development of the MFSP.

Neither the EPEA nor the $C R R$ had any retroactive effect in terms of security requirements for oil sands mining projects approved under the Land Surface Conservation and Reclamation Act. ${ }^{49}$ Where land was disturbed after 1 September 1993 pursuant to a development and reclamation approval issued under the LSCRA, the amount of security was determined in accordance with the LSCRA and its Regulations. The Security Deposit Ministerial Regulations, ${ }^{50}$ promulgated under the LSCRA, required an applicant for a development and reclamation approval to give security of $\$ 100,000$ for an oil sands site that by normal continuous operation produced synthetic crude oil at a rate of less than 100,000 barrels per day, or $\$ 250,000$ for an oil sands site producing synthetic crude oil at a rate of more than 100,000 barrels per day. ${ }^{51}$ Holders of a development and reclamation approval were required to give additional security at a rate of not less than three cents per barrel of synthetic crude oil actually produced (the actual rate was to be set by the Minister). ${ }^{52}$ As a result, both Suncor's Base Mine and Syncrude’s Base Mine reclamation security obligations were "grandfathered" under the prior legislation.

Under the prior reclamation regime, section 19 of the $C R R$ provided that security could be apportioned across parts of the specified land by the Director. Furthermore, the amount of security required for an approval could be increased or decreased if:

(a) the cost of future conservation and reclamation changes,

(b) the activity on the specified land is increased or reduced,

(c) the specified land or any portion of it is conserved and reclaimed,

(d) the conservation and reclamation plan in an approval is changed,

(e) the operator is conducting on the specified land more than one activity for which security is required, or

(f) any other circumstances exist that may increase or decrease the estimated cost of conservation and reclamation. $^{53}$

The security could be given by a variety of highly secured means (cash, cheques, government guaranteed bonds, debentures, term deposits, certificates of deposit, trust certificates or investment certificates assigned to the Minister of Finance and Enterprise, or

Alberta Wilderness Association, "Kakwa: History,” online: Alberta Wilderness Association <http:// albertawilderness.ca/issues/wildlands/kakwa/history> [Kakwa].

RSA 1980, c L-3 [LSCRA], as repealed by Environmental Protection and Enhancement Act, SA 1992, c E-13.3, s 247.

Alta Reg 242/82, as repealed by the CRR, supra note 37, s 25(5) .

Ibid, s 12 .

Ibid, s 13.

Ibid, s 20(1), as repealed by Alta Reg 34/2011, s 5. 
any other form acceptable to the Director $)^{54}$ but in the oil sands and coal industries, security has historically been provided exclusively by irrevocable letters of credit. Security was held separately in the Environmental Protection Security Fund and administered by the Minister of Environment. ${ }^{55}$

Under the prior reclamation regime, the security could be returned in whole or in part to the operator when a reclamation certificate was issued with respect to all or part of the specified land, as the case may be.$^{56}$ However, where section 15 of the CRR applied, the Minister could withhold all or part of the security until the applicable time period referred to in that section had expired. ${ }^{57}$ Section 15 states:

Where a reclamation certificate is issued ... to an operator in respect of [inter alia, the construction, operation, or reclamation of an oil sands mine], no environmental protection order regarding conservation or reclamation may be issued..

(a) more than 5 years after the date of issuance of the reclamation certificate, in a case where no approval in respect of the activity was held on the date of issuance of the reclamation certificate, or

(b) after the date of issuance of the reclamation certificate ... where an approval was held in respect of the activity on the date of issuance of the reclamation certificate.

This provision may allow an operator to avoid longer term liability, yet there does not appear to be any underlying rationale for the exemption.

Where the reclamation was partially complete, a portion of the security could be returned on application by the operator. ${ }^{58}$ When an operator failed to comply with an environmental protection order, an emergency environmental protection order, or an enforcement order, and that failure may have prevented or otherwise interfered with the conservation and reclamation of specified land, the Minister could order that all or part of the operator's security be forfeited. ${ }^{59}$ Where the Minister ordered the security to be forfeited, it was transferred from the Environmental Protection Security Fund to the Environmental Protection and Enhancement Fund, where it could be used by the Minister to conserve or reclaim lands as necessary. ${ }^{60}$ Note that no public notice of any of these events was required under the relevant legislation. As such, an operator may have been in default and its security may have been forfeited without any public notice or involvement.

\section{B. EARLY ATTEMPTS TO IMPROVE THE SYSTEM}

More than a decade ago the Auditor General of Alberta identified that the amount of security required by the Ministry of Environment, in order to ensure parties completed

Ibid, s 21.

EPEA, supra note 36 , s 32.

CRR, supra note 37 s 22(1).

Ibid, s 23.

Ibid, s 22(2).

Ibid, s 24(1).

EPEA, supra note 36, s 31, as repealed by Financial Statutes Amendment Act, SA 2003, c 2, s 1(24)(c). 
conservation and reclamation activities for disturbed land, was inadequate and the process for obtaining it was inconsistently applied. ${ }^{61}$ In the 1998-1999 Annual Report of the Auditor General, a recommendation was made that the Ministry implement a financial security risk assessment model, and the Auditor General stated:

Financial security, usually in the form of a letter of credit at a bank, is intended to cover the costs related to eventual site reclamation... My review suggests that some types of projects are required to provide financial security, while others are not. For those that are required to provide security, differing methods were used to evaluate the need for and actual amount of financial security. In some cases, the security is based on the estimated cost of reclamation; in other cases it is based on an estimate of the value of permanent structural improvements. $^{62}$

To address the noted issues, in 1999 the Government of Alberta, along with other stakeholders, developed a Financial Security Risk Assessment Model. ${ }^{63}$ This model consisted "of an activity screening process, environmental and economic risk assessment surveys, and a matrix to calculate the amount of financial security required for the proposed activity." 64 In addition, this model also took into account the applicant's financial health and the likelihood of success of the applicable venture. ${ }^{65}$ The model, once completed by an oil sands mine operator, was to be submitted to the Alberta Environment, at which point one of the six regional offices would determine the need for financial security to be provided. ${ }^{66}$

At first glance, this proposal seemed like a comprehensive approach to mine reclamation security. But the fact that a completed financial model was not reviewed by a centralized office raised some concerns on the part of the Auditor General of Alberta. The Auditor General's office was critical of the complex process proposed for obtaining security and expressed further concerns that the criteria would be inconsistently applied:

In our 1998-99 Annual Report ... we recommended that the Department implement the Financial Security Risk Assessment Model.... The Model addressed our concerns that the process for determining the amount and type of security for projects that could cause an adverse impact on the environment should be prudent and consistent across the Province. While we expressed concerns about the skill sets required to administer the Model, we felt that it would be an improvement over the existing situation.

[R]ecent events caused the Department to reconsider the appropriateness of the Model. For example, the recent bankruptcy of Smoky River Coal Limited may leave the Province at least partially responsible for site restoration costs. ${ }^{67}$

61 “The Case for Clear Rules on Oil Sands Reclamation Deposits: Despite Repeated Calls from Alberta's Auditor General, a Patchwork of Standards Persists,” Alberta Oil (1 February 2011), online: Alberta Oil Magazine <http://www.albertaoilmagazine.com/2011/02/alberta's-auditor-general-calls-for-clear-ruleson-reclamation-deposits/> [Alberta Oil].

62 Auditor General of Alberta, Annual Report of the Auditor General of Alberta: 1998-99 (27 September 1999) at 158 [1998-99 Report].

Alberta Oil, supra note 60.

1998-99 Report, supra note 62 at 158.

Ibid.

Ibid.

Auditor General of Alberta, Annual Report of the Auditor General of Alberta: 1999-2000 (3 October 2000) at 103-104. 
In July 1998, Smoky River Coal Ltd (Smoky River) was placed under the Companies' Creditors Arrangement Act ${ }^{68}$ protection by its secured lenders. In the midst of the CCAA order, Smoky River successfully applied to the Alberta Energy and Utilities Board (EUB) for approval to extend its mining pits. Despite protests from interveners that the mine extensions would have a significant detrimental effect on the environment, Smoky River's applications were approved without a hearing. ${ }^{69}$ In February 2000, Smoky River laid off 41 workers and announced debts of $\$ 130$ million. $^{70}$ By March 30, all mining operations had ceased and the coal leases were returned to the Crown. One of Smoky River's most significant coal mining pits (B2) "had reached its maximum area of land disturbance" without any reclamation having been done to the pit or the associated waste dumps. ${ }^{71}$ Thus, when the coal leases were returned to the Crown, all of the land reclamation was outstanding. Smoky River had posted \$7.1 million in reclamation security with the Crown, but the estimated cost to restore and reclaim the relevant area was estimated at $\$ 13.5$ million, leaving taxpayers responsible for the remaining cleanup costs of around $\$ 6.4$ million. ${ }^{72}$ However, it is difficult to get a full understanding of the actual costs to the taxpayers regarding the Smoky River Mine reclamation work for the very reasons described above. No public database or record could be found detailing the liability assumed by the Government of Alberta to clean up the relevant mine site before the leases were reissued. What is evident is that insufficient funds had been obtained by the Government of Alberta at the time of Smoky River's receivership to cover the costs of reclamation, leaving the taxpayers exposed. $^{73}$

Following the Smoky River bankruptcy issues, Alberta Environment, in what might be described as a "knee-jerk" reaction, declared that full-cost security would now be required for all oil sands and coal mines in Alberta. Industry reacted strongly to that declaration, knowing that the requirement to post upfront security for the full cost of reclamation would be such a financial burden that it would prevent projects from being undertaken in the first place.

By the end of 2001, the Government of Alberta had decided to not implement the Financial Security Risk Assessment Model, but had not put into place any other mechanism to assess financial risks, leaving the system unchanged. In its 2000-2001 and 2004-2005 reports, the Auditor General again stated that the Ministry of Environment's progress in

RSC 1985, с C-36 [CCAA].

Applications by Smokey River Coal Limited for Amendment of Permit No C97-13 and Licenses for Proposed No 12 Mine South B2 Pit Development, EUB Decision 98-10 (24 April 1998).

Kakwa, supra note 48.

Ibid.

Ibid.

The Smoky River bankruptcy is but one of a number of taxpayer-funded reclamation problems in Canada's mining industry. Royal Oak Mines conducted 50 years of gold mining outside Yellowknife at Giant Mine before it went bankrupt in April 1999, leaving an estimated \$200 million in environmental liabilities held against a $\$ 400,000$ performance bond. The reclamation costs are now being funded by the Canadian taxpayers. Robert Repetto, Silence is Golden, Leaden and Copper: Financial Disclosure of Material Environmental Information in the North American Hard Rock Mining Industry (Montreal: Commission for Environmental Cooperation, 2004) at 25, online: Yale School of Forestry \& Environmental Studies <http://environment.research.yale.edu/documents/downloads/o-u/repetto_report_ full.pdf > . The Faro Mine in the Yukon has an estimated \$700 million in environmental liabilities which are now being funded by the Canadian taxpayers following the bankruptcy of the operator in 1998. Cleanup of the zinc and lead extraction mine is estimated to take up to 40 years. Faro Mine Remediation Project, "Reference: Frequently-Asked Questions," online: Faro Mine Remediation Project<http://www. faromine.ca/reference/faq.html>. 
addressing the risks related to financial security for land disturbances by the oil sands mining industry was "unsatisfactory."74

Compounding the concerns raised by the Auditor General of Alberta were criticisms raised by taxpayers, environmentalists, commentators, and interveners at regulatory approval processes. Notably, the prior reclamation regime was criticized for its lack of transparency and inconsistent methodology applicable to the calculation of reclamation security. ${ }^{75}$ Reclamation cost estimates were provided by the operator and were not available for public review. Moreover, there were no regulations in place to ensure consistency in the cost estimation process. As a result, there was a constant concern that the reclamation security program was underfunded, leaving the Alberta government, that is, the taxpayers, on the hook for any shortfall. Dean Watt, in his report Seeking the Right Balance: Financial Security for Conservation and Reclamation of Alberta's Oil Sands Mines stated:

\begin{abstract}
The entire reclamation security process [was] characterized by its complete lack of public involvement. From the initial estimate and approval of the reclamation security amount, through annual adjustments and, ultimately, the return of the security to the operator, the regulator's discretion [was] exercised without allowing for public input into either the adequacy of the security amount taken or the reclamation work performed.... The lack of meaningful opportunities for public participation [was] the most clearly identifiable and significant failing of [the previous] oil sands mining reclamation security regime. ${ }^{76}$
\end{abstract}

\title{
C. AdDitional Issues With the Prior Reclamation Regime
}

In addition to the general overarching concerns with the prior reclamation regime, there were other more specific issues that needed to be addressed. One example relates to the various definitions that were intended to provide the framework for oil sands reclamation. "Conservation" is defined as "the planning, management and implementation of an activity with the objective of protecting the essential physical, chemical and biological characteristics of the environment against degradation."77 "Reclamation" is defined as any or all of the following:

(i) the removal of equipment or buildings or other structures or appurtenances;

(ii) the decontamination of buildings or other structures or other appurtenances, or land or water;

(iii) the stabilization, contouring, maintenance, conditioning or reconstruction of the surface of land;

(iv) any other procedure, operation or requirement specified in the regulations. ${ }^{78}$

Auditor General of Alberta, Annual Report of the Auditor General of Alberta: 2000-2001 (26 September 2001) at 90. Auditor General of Alberta, Annual Report of the Auditor General of Alberta: 2004-2005 (22 September 2005) at 177.

Pembina Institute, “Toxic Liability Fact Sheet: How Albertans Could End Up Paying for Oil Sands Mine Reclamation” (September 2010), online: Pembina Institute <http://pubs.pembina.org/reports/ toxicliabilityfactsheetfinal.pdf $>$.

76 Dean Watt, Seeking the Right Balance: Financial Security for Conservation and Reclamation of Alberta's Oil Sands Mines (Ottawa: Library and Archives Canada Cataloguing in Publication, 2010) at 87, online: Environmental Law Centre <http://www.elc.ab.ca/content_Files/Files/Seekingtheright balancewebcopydlfinal.pdf $>$.

77 EPEA, supra note 36, s 1(l).

78 Ibid, s 1(ddd). 
The conservation and reclamation must be carried out in accordance with the terms and conditions of any applicable approval or code of practice, the terms and conditions of any environmental protection order regarding conservation and reclamation, the instructions of an inspector or the Director, ${ }^{79}$ and the applicable provisions of the EPEA. ${ }^{80}$ Contrast these requirements with those of the $C R R$, which provides that the objective of conservation and reclamation of specified land is to return the specified land to an equivalent land capability, ${ }^{81}$ meaning "the ability of the land to support various land uses ... similar to the ability that existed prior to an activity being conducted on the land, but that the individual land uses will not necessarily be identical." ${ }^{82}$ In respect of oil sands mining reclamation, Alberta Environment interprets this to mean similar to undisturbed boreal forest, although this is not specified anywhere in the relevant legislation. ${ }^{83}$

Clear definitions and standards applicable to oil sands reclamation activities are essential for any reclamation security regime. Where too much latitude exists, stakeholders are far less likely to agree on what the applicable standards are, and therefore, are less likely to agree on how to assess the required costs to achieve those standards. As stated in the Expert Panel Report:

[I]nterpretation of reclamation standards has potential to shape decisions and actions of all stakeholders in the oil sands. These interpretations allow oil sands critics to say [industry has] not reclaimed to appropriate standards by focusing on different definitions of reclamation and restoration than those of the regulators and operators. They allow operators to further interpret what is expected and required based on what they think can be accomplished in a reasonable time-frame at a reasonable cost. They allow policy makers to balance industrial development with environmental protection and economic development. Such interpretations allow all stakeholders to think they are right and therefore never reach an agreement. ${ }^{84}$

This Expert Panel Report states that if “an agreed-upon specific end land use” is clearly set out, stakeholders can independently assess the costs of reclamation and the potential longterm effects, and are more likely to come to similar conclusions. ${ }^{85}$ Further, it recommends that before an approval for a project is granted, the accepted end land uses with defined goals and achievement markers be established. ${ }^{86}$ The authors concur that the new reclamation regime needed to contain clearly defined standards and expectations for reclamation so that the endless debates and controversy over industry's alleged non-compliance, the government's alleged apathy and pro-development stance, and other stakeholders' alleged unrealistic expectations can finally cease.

Under the prior reclamation regime, there was no requirement for ongoing, progressive reclamation, and as a result, no legislative incentives to conduct reclamation in stages. To date, only one oil sands mining site measuring 104 hectares has received a reclamation

\footnotetext{
79 "Director" means a person designated as Director for the purposes of EPEA by the Minister responsible for the Act. Ibid, s $1(\mathrm{r})$.

Ibid, s 137(2).

Supra note 37, s 2.

Supra note 28 at 158 [emphasis omitted].

Ibid at 157.

Ibid at 164 .

Ibid at 165 .

Ibid.
} 
certificate. ${ }^{87}$ This site, known as Gateway Hill, “was used for the placement of overburden material removed during oil sands mining" and was replanted and reclaimed in the early 1980s by Syncrude Canada Ltd (Syncrude) ${ }^{88}$ However, Syncrude did not receive a reclamation certificate until 2008. ${ }^{89}$ A further 4,654 hectares of lands previously disturbed by oil sands mining is in the process of being reclaimed but has yet to receive certification..$^{90}$ Given how little land has been certified as reclaimed to date, it is no wonder that the public expresses concerns over how seriously the government takes reclamation. ${ }^{91}$

In respect of the grandfathered projects under the $L S C R A$, basing the amount of security that is required on production, rather than the estimated costs of reclamation, seemed questionable (as the amount of production may bear no relevance to the actual costs of reclamation) and created a risk that the security program would be underfunded, thereby become a potential taxpayer liability.

Another issue related to the Director's very broad mandate under section 18(1) of the CRR to determine security requirements and their discretion to determine what constituted sufficient security. The prior reclamation regime did not prescribe any methodology to be used to quantify reclamation costs. Nor, in the authors' view, did it provide sufficient direction or parameters, especially given the complexity of reclamation work, leaving open a risk that operators may have underestimated those costs. Moreover, without comprehensive estimation guidelines, there were bound to be inconsistent approaches to these calculations. As such, even between operators (and within industry) there was likely concern regarding the potential for another project to be underfunded. If that underfunded project suffered serious financial problems, the entire industry's reputation would be adversely impacted. This problem could be rectified if the reclamation calculation methodologies were fleshed out and vetted by an independent party or the regulator. Because public review of the cost estimates is not currently available, it is not possible to determine whether any of these criticisms of the prior reclamation regime are unfair.

Under the prior reclamation regime, an operator could apply to have its security returned prior to obtaining a reclamation certificate, where the reclamation had been partially completed. ${ }^{92}$ This process was managed by the Director with no ability for public input. Again, given taxpayers are ultimately responsible for underfunding, at the very least, public review should be made possible.

The EPEA's broad definition of reclamation includes the requirement to remove equipment, buildings, and other structures, ${ }^{93}$ but oil sands mine approvals do not cover these activities as part of reclamation — an omission that seems questionable. As stated by Watt,

Reclamation, supra note 20 .

Government of Alberta, News Release, “Alberta issues first-ever oil sands land reclamation certificate” (19 March 2008), online: Government of Alberta <http://alberta.ca/home/NewsFrame.cfm?ReleaseID=/ acn/200803/23196C8880E90-A0E1-9CE0-1B3799BC38A51E 3E.html>.

Reclamation, supra note 20.

Ibid.

Including the land noted above, a total of 66,342 hectares of land in Alberta has been disturbed by oil sands mining. Ibid.

CRR, supra note 37, ss 22(1)-(2).

Supra note 36, s 1(ddd). 
there is no known policy reason for this exclusion. ${ }^{94}$ It stands to reason that the scope of required reclamation should cover all aspects of an oil sands mining project, including the extraction and other related facilities.

\section{The New Mine Financial Security Program}

In order to implement the MFSP, the Government of Alberta made several amendments to the $C R R$ and published the Mine Financial Security Program Standard, ${ }^{95}$ which is incorporated into the $C R R$ pursuant to section 16.1. Section 18(1.1) of the $C R R$ requires the amount of security for a mine approval (which now specifically refers to an oil sands mine or a processing plant $)^{96}$ to be determined in accordance with the MFSP Standard, and section 20(1) now states that any adjustment of the security for a mine approval must be conducted in accordance with the MFSP Standard. Section 20.1 provides that notwithstanding anything contained in section 20, the operator may be required to furnish an updated estimate of security, and the operator will be required to provide any updated security amount approved by the Director within the time period specified by the Director. Furthermore, the grandfathering of older oil sands mine sites under predecessor legislation has been eliminated.

The MFSP is based on principles similar to those set out in the Large Facility Liability Management Program that the ERCB has implemented for the conventional oil and gas industry in Alberta: surface disturbances from an operator's projects are liabilities, and future production from those projects are assets. ${ }^{97}$ In a nutshell, the Guide to the Mine Financial Security Program provides that where an Approval Holder has MFSP Assets equal to or greater than three times their MFSP Liabilities, "is 15 years or more from the end of its reserves," and is in compliance with its progressive reclamation under an approved reclamation plan, no additional security is required to be posted with the Government of Alberta other than the "base" amount of security (now called the "Base Security Deposit"). ${ }^{98}$ If any of the above noted circumstances are not met, the requirement to post additional financial security is triggered. The MFSP Guide intends that each project "secures" its mining reclamation liabilities with its associated assets, recognizing that where the relevant asset value diminishes (through either depletion of reserves or falling commodity prices), the Approval Holder has to switch from asset security to financial security to be held by the government. $^{99}$

The MFSP Standard defines the "Approval Holder" as the party that is issued the approval under the EPEA for the relevant project. ${ }^{100}$ Since the obligations are based on an "approval," all asset, liability, and financial security under the MFSP are calculated and posted separately on an individual project basis. ${ }^{101}$ In addition, the government looks only to the Approval

Supra note 76 at 90 .

Alberta Environment, Mine Financial Security Program Standard (Edmonton: Alberta Environment, 2011) [MFSP Standard].

CRR, supra note 37, s 16(d).

ERCB, Directive 024: Large Facility Liability Management Program (Calgary: ERCB, 2009).

Alberta Environment, Guide to the Mine Financial Security Program (Edmonton: Alberta Environment, 2011) at 6 [MFSP Guide].

Ibid at 8.

Supra note 95 at Definitions, ss 2(f)-(g).

MFSP Guide, supra note 98 at 10. 
Holder for compliance with all of the new reporting obligations and the posting of the requisite financial security. ${ }^{102}$ While joint owners of a mine may provide a portion of the financial security required under the MFSP Standard for or on behalf of the Approval Holder, the proposed legislation does not require this; only the Approval Holder is obligated to post security for reclamation liabilities. ${ }^{103}$ Having said that, other participants in an oil sands mining project can be compelled to carry out (that is, pay for) the required reclamation if the Approval Holder fails to do so. ${ }^{104}$

The MFSP is made up of the following four distinct financial security deposits; the Base Security Deposit; the Asset Safety Factor Deposit; the Operating Life Deposit; and the Outstanding Reclamation Deposit, ${ }^{105}$ each of which is briefly described below. The requirement to pay each deposit is contingent on certain facts being established.

\section{A. The Base Security Deposit}

Every Approval Holder must provide a Base Security Deposit, except in very limited circumstances. ${ }^{106}$ The Base Security Deposit is intended to provide immediate funds to the government to cover the short term financial risks associated with an unexpected suspension of mining operations, plus additional funds to address some of the other potential associated risks. ${ }^{107}$ The amount of the Base Security Deposit that is to be paid depends on whether a project has an approval as of 31 December 2010. For those projects that have an approval as of that date, the amount of the Base Security Deposit is the amount of security now held by the government in respect of that project. ${ }^{108}$ In other words, none of the currently held security is being released by the government upon implementation of the MFSP. For oil sands mines with an approval as of 1 January 2011, the Base Security Deposit is $\$ 30,000,000$, and for oil sands mines with upgraders without an approval as of January 1 , 2011 , the Base Security Deposit is $\$ 60,000,000 .{ }^{109}$ It is intended that the adequacy of these amounts will be reviewed every three years, allowing the government to increase (or decrease) the amount of security required for these deposits for inflation and other factors, thereby avoiding the implementation of arbitrary security amounts that could make certain mines not economically viable.

\section{B. The AsSET SAFETy FACtor Deposit}

The requirement to pay an Asset Safety Factor Deposit is triggered when the Approval Holder's MFSP Asset value falls below three times the value of the associated MFSP Liabilities, less the value of the Operating Life Deposit and the Base Security Deposit. ${ }^{110}$ The latter two deposits are included in the equation as these amounts can be used to offset the

\footnotetext{
$102 \quad$ Ibid at 5.

$103 \quad$ Ibid at 6 .

$104 \quad$ Ibid at 10.

105 A table comparing the four financial security deposits is found ibid at 24-25.

106 A Base Security Deposit is not required if the Approval Holder has elected to provide full security. MFSP Standard, supra note 95, at 9.

MFSP Guide, supra note 98 at 25.

Ibid at 26.

These amounts may be adjusted on approval of the Director, provided that an independent third party assessment confirms that they are too high in relation to the relevant project. Ibid at 25-26. Ibid at 26.
} 
Approval Holder's total reclamation liabilities. ${ }^{111}$ This ratio of the MFSP Assets to MFSP Liabilities (less the other deposits described above) is referred to as the Adjusted Asset Safety Factor. The amount that is required under this deposit category is the amount necessary to bring the Adjusted Asset Safety Factor back to 3.00. ${ }^{112}$

\section{The Operating Life Deposit}

The Operating Life Deposit addresses the risk that occurs when an Approval Holder's oil sands mine is nearing the end of its reserve life and the participants in that mine will not have sufficient MFSP Assets to fund the associated MFSP Liabilities. ${ }^{113}$ The amount of the Operating Life Deposit is a function of the Reserve Life Index ${ }^{114}$ for the mine and the amount by which the Operating Life Deposit exceeds the Base Security Deposit. Fifteen years prior to the end of the life of a mine, the Approval Holder is required to determine the thenremaining reclamation costs (including the cost of post-closure reclamation and monitoring) and post 10 percent of that amount in each of the next ten years, so by the time that the end of the life of a mine is less than six years away, the reclamation liabilities will be fully secured. ${ }^{115}$ Using the vernacular of the MFSP, where the Reserve Life Index of an oil sands mine is less than 15, the initial Operating Life Deposit is 10 percent of the associated MFSP Liability. ${ }^{116}$ The applicable percentage increases by 10 percent for each succeeding year, until the Reserve Life Index of the mine is less than six, in which case the Operating Life Deposit is calculated as 100 percent of the MFSP Liability. ${ }^{117}$

If the initial Operating Life Deposit is less than the Base Security Deposit, no amount is payable on account of the Operating Life Deposit. If the initial Operating Life Deposit is greater than the Base Security Deposit, the Operating Life Deposit is the difference between the two amounts. ${ }^{118}$ There are a few other important considerations related to the Operating Life Deposit, such as the fact that in-situ production that is owned by an Approval Holder and shipped to an upgrader that is covered under the MFSP will be included in the Reserve Life Index calculation, but reserves associated with third party production are not. ${ }^{119}$ As reclamation is completed over the final five years of a mine's life, the Operating Life Deposit will be reduced accordingly. It is worth noting that the Operating Life Deposit is a "made-inAlberta," first of its kind program, designed specifically for coal and oil sands mining reclamation. It will be interesting to see whether other jurisdictions implement a similarly structured deposit.

114 The Reserve Life Index is calculated as the gross proven plus probable reserves of the relevant mine divided by the three-year average annual sales volume. Ibid at 28.

Ibid at 6.

Ibid at 27.

Ibid at 27-28.

Ibid at 28.

Third party production from in-situ wells of another Approval Holder may be included in an Approval Holder's netback calculation, but not the Reserve Life Index calculation. Ibid at 30. 


\section{The OUTSTANDing REclamation DePosit}

The Outstanding Reclamation Deposit is designed to encourage Approval Holders to proactively and progressively manage their reclamation liabilities by making the cost of deferred reclamation greater than the cost of current reclamation. ${ }^{120}$ Each Approval Holder is required to submit a reclamation plan (Current Reclamation Plan) in which they must identify the number of hectares of permanent land reclamation proposed for completion in each year. ${ }^{121}$ A Current Reclamation Plan has to be updated every three years and must set out the proposed activities ten years into the future. ${ }^{122}$ If the government believes that an Approval Holder is deferring the scheduling of reclamation activities, it can order that Approval Holder to start reclamation work and it is up to the Approval Holder to demonstrate that starting the work would be contrary to good reclamation practices or the efficient and economic development of the resource. ${ }^{123}$

On an annual basis, an Approval Holder is required to calculate the difference between the planned reclamation under its Current Reclamation Plan and the actual reclamation completed in that year. ${ }^{124}$ The MFSP Standard refers to an Approval Holder's obligation to undertake "Planned Reclamation," 125 while the MFSP Guide refers to "permanent reclamation."126 The MFSP Guide states that permanent reclamation will be deemed complete only when any given area has been reclaimed "consistent with the final end land use objectives required by the Approval," ${ }^{127}$ although a reclamation certificate does not have to be issued for lands to qualify as permanently reclaimed for the purpose of the Outstanding Reclamation Deposit. The MFSP Standard does not define "Planned Reclamation."

Alberta Environment reports that reclamation costs "of oil sands mines can range from $\$ 45,000$ per hectare to $\$ 75,000$ per hectare,”128 although some commentators have speculated that this number can be as high as $\$ 200,000$ per hectare for certain types of reclamation. ${ }^{129}$ In calculating the Outstanding Reclamation Deposit, the Approval Holder is asked to calculate its Cumulative Reclamation Balance, which is the sum of all Annual Reclamation Balances (positive and negative) to date. ${ }^{130}$ Where an Approval Holder fails to reclaim all of the lands that it proposed to reclaim in that year, it creates an Annual Reclamation Balance, which is then added to its Cumulative Reclamation Balance. Conversely, where an Approval Holder manages to reclaim more lands than proposed in its Current Reclamation Plan, it receives a credit against its Cumulative Reclamation Balance. The Cumulative Reclamation Balance is then multiplied by $\$ 75,000$ and the resulting amount has to be submitted as an Outstanding Reclamation Deposit. ${ }^{131}$ The Outstanding Reclamation Deposit security is refunded to the Approval Holder as the Cumulative Reclamation Balance is reduced over the

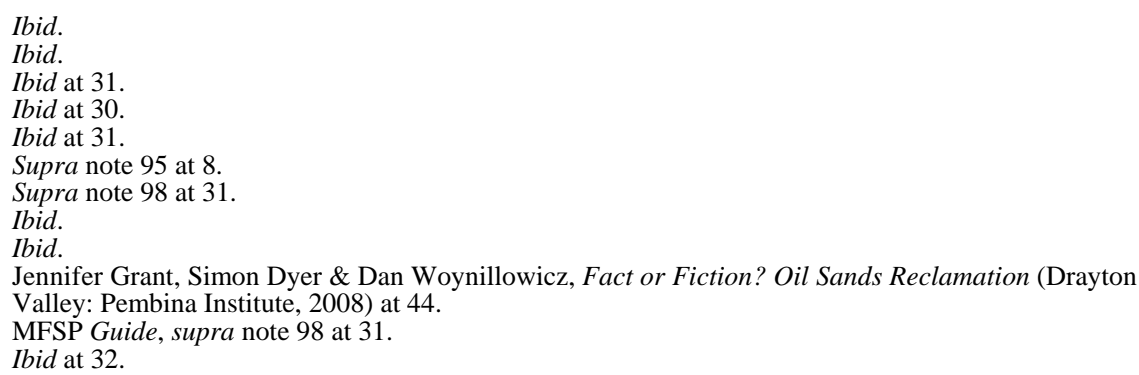


years. There is also potential for an adjustment to be made to the Cumulative Reclamation Balance in circumstances where unforeseen changes occur in the corresponding Current Reclamation Plan that could not have been anticipated by a prudent Approval Holder. ${ }^{132}$ Under the prior regime, industry and Alberta Environment disagreed as to what the reclamation standards for an oil sands mine should be, making undertaking some types of reclamation a bit of a gamble in that an operator that undertakes reclamation could be asked to reverse the work and start again — an obviously costly endeavour. Now, with the creation of reclamation standards, regulatory certainty has been built into the program, which in turn should encourage operators to conduct progressive reclamation.

\section{E. Providing THE Necessary SECURITY}

Under the MFSP, reclamation security is calculated and adjusted annually and will generally be equal to the sum of the four deposits referred to above. If, however, this amount exceeds the MFSP Liability for that Approval Holder, the aggregate of such financial security required will be adjusted downwards, to equal the amount of the MFSP Liability. ${ }^{133}$ As under the prior reclamation regime, financial security can be cash, but is most likely to be in the form of a letter of credit or other form of security, as approved by the Director. ${ }^{134}$

As discussed above, the Approval Holder is the party responsible for submitting the requisite financial security under the MFSP on time. Failure to comply with the MFSP obligations may open an Approval Holder up to fines and other penalties. ${ }^{135}$

\section{F. CERTIFICATION OF MFSP ASSET AND LiABILITy DATA}

In an attempt to ensure the MFSP information supplied by the Approval Holder is accurate and consistent with the requirements of the legislation, there is now a requirement that the $\mathrm{CEO}$, CFO, or the designated financial representative (for "joint venture partnerships only") ${ }^{136}$ must certify that, based on knowledge, the values reported in the MFSP Asset, MFSP Liability, Outstanding Reclamation Deposit, and Financial Security Information sections of the MFSP Annual Report are true and accurate representations of the MFSP requirements, with the qualification that the certification of any estimates that form part of the MFSP Asset and MFSP Liability calculations “only attests that appropriate procedures were used to determine their value and the resulting estimate is reasonable." 137 It is a very high standard to require executive sign-off on liability estimates and security calculations, and, in the authors' experience, these types of certifications are taken very seriously by senior management. ${ }^{138}$ This should provide significant comfort to the public that a high

\footnotetext{
132 Ibid.

$133 \quad$ Ibid at 34.

$134 \quad$ Ibid at 34, 54

$135 \quad$ Ibid at 48

136 This note is included in Schedule 2 of the MFSP Standard as part of the Corporate Certification. It is unclear whether a designated financial representative may make this certification for only partnerships or joint ventures, as opposed to "joint venture partnerships.” The safest course is to have the CEO or CFO of the Approval Holder execute the certification. Supra note 95 at 18.

138 Sections 227(a) and (b) of the EPEA provide that it is an offence to knowingly provide or provide false
} information. Supra note 36, ss 227(a)-(b). 
priority has been placed on accuracy and completeness in the preparation of the MFSP Annual Report.

One of the strongest criticisms of the prior reclamation regime was the lack of public access to information regarding the liabilities, financial security, and reclamation progress of Approval Holders. Accordingly, a key component of the success of the MFSP has to be more and more transparent information regarding oil sands mining reclamation. Under the MFSP, Alberta Environment's website will contain the amount of the Asset Safety Factor Deposit, the amount of each of the types of financial security provided by each Approval Holder, and the aggregated amount posted by sector, as well as the status of current reclamation for each mine as measured against the corresponding mine's Current Reclamation Plan. ${ }^{139}$ Certain confidential and commercially sensitive information will be protected, and in this regard, each mine's individual asset and liability numbers will not be disclosed publicly. The expectation is that as a result of the increased amount of information available for public scrutiny and the higher onus on each Approval Holder's CEO, CFO, or designated financial representative to certify reclamation obligation calculations according to pre-established methodologies, all stakeholders will be able to gain a better understanding of the outstanding reclamation obligations associated with the oil sands mining industry in Alberta.

Within days of the MFSP being announced, a number of concerns were publicized. While the Pembina Institute, a well-regarded watchdog of the oil sands industry, applauded the Government of Alberta's move towards accountability and transparency, it was skeptical that the Outstanding Reclamation Deposit would achieve the desired result. As stated by Nathan Lemphers in a Pembina Institute blog: "If the mine reclamation plans are not sufficiently ambitious and do not reflect the government's desire to increase the rate of reclamation, then this type of deposit will provide no financial signal at all to oilsands mine operators."140

One factor that might mitigate this concern is the government's ability to audit the contents of any Approval Holders' MFSP Annual Report. Under the MFSP Standard, the Director has "reasonable access" to any data or reports the Director thinks it needs to see as well as to the Approval Holder's staff or consultants who prepared the report. ${ }^{141}$ Deficiencies identified in the audit have to be remedied by the Approval Holder within a specific time period, which can include the provision of additional security. ${ }^{142}$ The authors believe that this concern should be alleviated due to the government's role as the regulator of oil sands reclamation, ensuring that Approval Holders are, in fact, being appropriately aggressive. This, coupled with the new public portal to assess each mine's progress towards reclamation, should discourage reclamation apathy.

Additional concerns were raised regarding the shift in the way that Alberta Environment will now manage oil sands liability issues, in particular, the proposed "asset-to-liability" approach, which is alleged to be "problematic for a number of reasons." "143 Lemphers points Pembina Institute (24 March 2011), online: The Pembina Institute <http:www.pembina.org/blog/513>. MFSP Standard, supra note 95 at 11.

Ibid.

Lemphers, supra note 140. 
out that an Approval Holder may be overly optimistic regarding the value of its oil sands assets and at the same time potentially underestimate the value of the associated liabilities. ${ }^{144}$ This criticism seems to ignore the fact that the Assessment Retirement Obligation Liability calculations used to calculate the MFSP Liability use the same standards as audited, publicly reported financial statements for the retirement of tangible long-lived assets and the associated asset retirement costs. ${ }^{145}$ Approval Holders that are issuers in Canada under applicable securities legislation also have to comply with National Instrument 52-109, ${ }^{146}$ which requires CEOs and CFOs to assess whether financial information included in interim and annual filings present fairly, in all material respects, the financial condition of the issuer. Similarly, the United States' Sarbanes-Oxley Act of $2002^{147}$ required CEOs and CFOs to certify the appropriateness of the financial statements contained in the issuers reports. ${ }^{148}$ These acts apply to all legal obligations of an issuer and would therefore encompass the Approval Holder's calculations under the MFSP.

Further, a series of questions were raised regarding whether the new MFSP is sufficiently flexible to deal with significant fluctuations in the price of oil (which will affect the MFSP Asset calculation) and how this might impact the ability to collect reclamation security. The government has sought to deal with the issue of oil price fluctuation and the impact of same on security calculations by relying on a three-year forward-looking price adjustment clause.

According to Lemphers with the Pembina Institute, collecting security as reclamation liabilities are accrued is a safer underlying approach to funding issues. ${ }^{149}$ While the Pembina Institute is no doubt correct in suggesting that a fully funded financial security program is a safer funding model, if Approval Holders are obligated to post full financial security for their projects, it is doubtful that many projects would be built.

Andrew Leach, an Associate Professor of Business at the University of Alberta, also had some interesting thoughts about the MFSP following its announcement. In "Rescuing the Frog: Andrew Leach’s Energy, Climate and Oil Sands Blog," ${ }^{150}$ he states that while deferred reclamation payments might actually positively impact the amount of money collected by the Government of Alberta under the oil sands royalty regime, ${ }^{151}$ "the costs of deferring the liabilities, in terms of both the incurred risk and the signal it sends to companies doing

$144 \quad$ Ibid.

145 Canadian Institute of Chartered Accountants, CICA Handbook - Accounting, Part II, Section 3110 (Ottawa: Library and Archives Canada Cataloguing in Publication, 2010) at 311.

146 Certification of Disclosure in Issuers’ Annual and Interim Filings, ASC NI 52-109 (1 January 2011), s $8.2(3)$.

Pub L No 107-204, 116 Stat 745.

Ibid, s 103(a)(2).

Supra note 140 .

Andrew Leach, "New Reclamation Guidelines (Wonkish)” (17 March 2011), online: Rescuing the Frog

<http://andrewleach.ca/oilsands/new-reclamation-guidelines-wonkish>.

Ibid, where Leach states:

There is a difference in royalty treatment with respect to when costs are incurred, because oil sands royalties have always "recognized any new environmental fees or levies as an eligible cost of doing business, and therefore deductible in determining royalties on oil sands projects...." If the payments are incurred up front, my reading is that these payments would fall under the attributable costs of a project, and would therefore extend the period over-which the facility would be subject to the gross revenue royalty of 1-9\% until costs had been fully paid back.... If the payments are made later, the Crown share of these costs would decrease somewhat. So, simply collecting the costs up-front is not necessarily a winning proposition for us, the resource owners. 
business here, is much higher than the potential savings on royalties or the potential increase

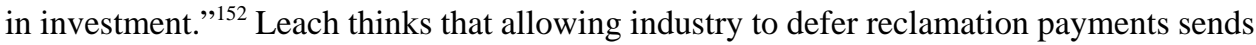
the wrong message that "the environment is of secondary concern and may be placed on the back burner to improve the investment environment.”153 The authors agree that a correct balance must be reached between holding operators accountable to ensure appropriate levels of reclamation work is ongoing and sufficient security is provided, on the one hand, and that on the other hand, the economics of project development are recognized to allow such projects to continue to be developed. If you allow the balance to shift too far one way or the other, the authors believe the system will ultimately fail. Achieving and maintaining the delicate balance should be the goal.

\section{RECLAMATION AND SECURITY ISSUES TO CONSIDER WHEN DRAFTING JoINT VENTURE AgREEMENTS}

Overall, improvements made by the MFSP will make the practitioner's task in drafting the abandonment and reclamation provisions of an oil sands joint venture agreement ${ }^{154}$ significantly easier. Nevertheless, the following features of the MFSP require careful consideration as part of the drafting exercise:

(a) Parties eligible to provide security. Although Alberta Environment will accept security deposits from non-operator joint venture participants (that is, those other than the operator ${ }^{155}$ ), the operator is ultimately responsible under the $C R R$ for ensuring that the required security is posted on time;

(b) Realization of security upon operator default. Where the operator defaults in the provision of security, Alberta Environment cashes all the security instruments at the same time;

(c) Full financial security is not required at all times during the project life cycle, reduced security is required in the early to middle stages of mine life, and full financial security is not required until the later stages of mine life;

(d) Security refunds. Alberta Environment may refund a security deposit directly to a joint venture participant rather than directly to the operator. ${ }^{156}$ The CRR does not specify to whom security should be returned where it has been posted by a party other than the operator. This raises questions regarding operator (and other nonoperator) exposure to financial risks; pursue the development and/or operation of an oil sands project, and "joint venture participant" is used to denote a party to a joint venture agreement.

The term "operator" is used in this part of the paper rather than "Approval Holder," to conform with typical joint venture vernacular.

MFSP Guide, supra note 98 at 38. 
(e) Transfer of an Approval Holder's Approval; and

(f) Return of security upon issuance of a reclamation certificate.

Each of these features will be examined in turn with potential drafting issues and suggested approaches identified.

\section{A. Parties Eligible to Provide Security}

The fact that the MFSP allows the operator and/or one or more of the joint venture participants to provide security means that the joint venture agreement must explicitly state the joint venture participants' preferred arrangements in this regard. As stated in the MFSP Guide:

Companies participating in MFSP mines and/or plants may provide their share of the required security to, or on behalf of, the Approval Holder. Participation includes being an owner, working interest participant, or a joint venture participant. Sharing of security is a business arrangement between the parties, not a requirement of the MFSP. ${ }^{157}$

As a result, a joint venture agreement needs to address whether security will be posted by the operator on behalf of the joint venture participants, by the joint venture participants themselves according to their participating interests, or whether the arrangement selected depends on the circumstances.

In circumstances where the operator posts security on behalf of the joint venture participants, a number of drafting issues will need to be addressed. First, whether it is within the operator's discretion to determine the type, form, and term of the security. Second, the joint venture agreement will need to provide that the operator's cost of providing security can be charged to the joint account. Third, whether the operator is able to require the other joint venture participants to provide backstop security. From the perspective of non-operators required to provide backstop security, the joint venture agreement should oblige the operator to ensure that non-operators are not disproportionately prejudiced by circumstances unique to each party.

Is any particular arrangement to be preferred? It is difficult to provide a categorical answer. The preferred arrangement will depend, inter alia, on the joint venture participants' financial circumstances and the financial market conditions. Accordingly, the authors' recommendation is to provide maximum flexibility in the joint venture agreement so that the operator (or management committee) can select the best arrangement for the situation.

Finally, where joint venture participants aside from the operator will be providing security, the default provisions of the joint venture agreement need to address their failure to properly do so, as the $C R R$ makes the operator ultimately responsible for providing the full amount of security required. ${ }^{158}$ If, for example, the government fines the operator, those costs can be 
passed on to the defaulting party; however, if the operator's other oil sands mine projects are somehow penalized due to a default in respect of a different mine, it becomes more difficult to properly remedy that default simply by the payment of damages. In these circumstances, the authors suggest that additional remedies, other than just an accounting for funds, be considered in the joint operating agreement.

\section{B. REALIZATION OF SECURITY UPON OPERATOR DEFAULT}

Where the operator fails to carry out its abandonment and reclamation obligations, Alberta Environment may require that all or part of the posted security be forfeited. ${ }^{159}$ However, the MFSP Guide states that the use of secured funds to carry out abandonment and reclamation is a "last resort." "160 Instead, Alberta Environment's preferred options include working with the operator's "partners (owners, joint venture partners, working interest participants, etc.) ... to find alternative solutions (e.g., a new [operator] takes over, the partners agree to do the work)."161

In light of this, practitioners should consider specifically including the failure to properly carry out abandonment and reclamation obligations as an operator default which may, at the election of the non-operators, allow one or more non-operators to work directly with Alberta Environment. The importance of this is also underscored by the fact that Alberta Environment is able, by virtue of the breadth of the EPEA definitions of "operator" and "person responsible," to take enforcement actions directly against joint venture participants. ${ }^{162}$ The MFSP Guide also notes that where an operator defaults in its obligations under the MFSP (which includes not just the obligation to post security, but, inter alia, the obligation to complete progressive reclamation operations and reporting obligations), the Approval may be suspended. ${ }^{163}$ As such, the other participants in a relevant mine (and lenders and other interested parties) may want the ability to step into the operator's shoes and take over operations in these circumstances.

\section{FULl FinANCIAL SECURITY NOT REQUIRED UNTIL LATER IN AN OIL SANDS PROJECT'S LiFE}

The principle that full financial security is not required by Alberta Environment throughout an oil sands project's life combined with the fact that an operator cannot access MFSP security to fund abandonment and reclamation activities potentially creates risks for the operator and other joint venture participants. A typical scenario (which the MFSP explicitly incentivizes) is that an operator will perform progressive reclamation throughout the life of an oil sands project. ${ }^{164}$ Provision for this work may be reflected in the operator's annual budgets and funded by a cash call mechanism.

However, a joint venture participant's failure to meet a cash call can jeopardize the joint venture's ability to fulfill its abandonment and reclamation obligations. While joint venture

Ibid, s 24.

MFSP Guide, supra note 98 at 36.

Ibid at 35.

See supra note 36 at ss 107(1)(c), 134(b), 147(b).

MFSP Guide, supra note 98 at 35.

Ibid at 30, 57. 
agreements usually have robust default provisions to deal with a joint venture participant's funding failure, not all of the remedies provide practical and timely recourse in this scenario. Accordingly, it is important for practitioners to consider and carefully assess the adequacy of the contractual remedies for this particular type of default.

In the recent context of drafting a joint venture agreement for an oil sands project, the authors created a mechanism known as a "contractual abandonment and reclamation fund" to ensure adequate funds are available to discharge each joint venture participant's abandonment and reclamation obligations throughout the life of the project. Very simply, the contractual fund was designed to provide immediate security for the ongoing performance of abandonment and reclamation activities. Where a joint venture participant fails to fund its budget commitments, the security could be quickly realized and abandonment and reclamation could continue while parallel default proceedings were undertaken against the joint venture participant. In this particular instance, the joint venture agreement would have provided that the decision to establish the contractual fund was within the purview of the management committee, while the determination of the funding level was the operator's duty.

\section{REFUND OF SECURITY DEPOSITS TO NON-OPERATORS}

Section 22 of the $C R R$ governs the return of security by Alberta Environment. It does not specify, however, to whom the security may be returned. Given that the CRR expressly allows joint venture participants other than the operator to provide security, it may be logical to assume that the security would be returned to the party that provided it. Assuming Alberta Environment would be prepared to return security directly to a non-operator joint venture participant, there may be circumstances where this may not be desirable from the perspective of the remaining joint venture participants. For example, where a joint venture participant unilaterally withdraws from the joint venture agreement or is compelled to forfeit its interest for default, the joint venture agreement typically provides that the participant remains liable for its pro rata share of abandonment and reclamation liabilities incurred while they were a party to the agreement. Where this is the case, it may be useful to include a provision in the agreement indicating that the party is not entitled to a return of security, and where the security is returned to a defaulting party, that they hold it in trust for the remaining joint venture participants. The effectiveness of this type of provision may depend on the form of security issued, returned, and credit-related issues.

\section{E. Transfer of APPROVAls}

The MFSP Standard provides very detailed requirements in terms of the transfer of either an entire Mine Approval or part of a Mine Approval. ${ }^{165}$ In a nutshell, where the entire Mine Approval is being transferred, the transfer application will not be approved until the transferee has provided a written undertaking to comply with the MFSP Standard and has provided security in the same amount and form as had been provided by the transferor. For partial transfers, both the transferor and transferee have obligations, which include the posting of security, providing updated MFSP calculations, and applying for deemed netback in order to calculate the MFSP Assets. 
From a drafting perspective, a simple approach may be to specify that a transfer of operatorship will not be effective until the requirements of applicable laws are fulfilled. As a refund of security will also occur, the suggestions in the previous section concerning refunds of security deposits should also be considered.

\section{F. RETURN OF SECURITY UPON ISSUANCE OF A RECLAMATION CERTIFICATE}

Section 22(1) of the CRR enables Alberta to return all or part of the security provided where a reclamation certificate is issued. However, despite the issuance of a reclamation certificate, there are circumstances under the EPEA where additional conservation or reclamation may occur. ${ }^{166}$ More generally, there is always the risk that laws may change after a reclamation certificate is issued. Accordingly, these types of risks must be addressed in a joint venture agreement. For example, it may be prudent from the perspective of all of the joint venture participants' to include wording that, despite the issuance of a final reclamation certificate, the participants shall remain liable according to their participating interests for any subsequent abandonment and reclamation claims.

\section{CONCLUSION}

Given the significant problems with the prior reclamation regime, the authors believe that stakeholders will recognize that the MFSP is a considerably improved reclamation program. There is potential for new or isolated problems to arise, as with every new program, but it is a big step in the right direction in that the MFSP addresses many of the issues that have been raised by detractors of the prior reclamation regime. It provides a uniform reclamation regime for all oil sands projects, sets out standards of reclamation, provides for ongoing reclamation according to established time frames, penalizes operators who ignore that responsibility, establishes transparent methodologies for the calculation of MFSP Assets and MFSP Liabilities, and generally provides a clearer, more disciplined reclamation regime designed specifically around the environmental disturbances created by the mining industry. While there is obviously an increased administrative burden to both industry (annual updates and MFSP calculations) and the Government of Alberta (scrutiny of same) to implement these new rules, this system seems far more likely to protect Alberta taxpayers, investors, and others from exposure to financial liability due to unfinished reclamation. 